\title{
Photosynthetic Performance, Nutrition and Growth of Campomanesia xanthocarpa O. Berg. in Chicken Manure Substrate and Liming
}

\author{
Ademir Goelzer ${ }^{1}$ (D) \\ Orivaldo Benedito da Silva ${ }^{1}$ (D) \\ Fernando Henrique Moreira Santos ${ }^{2}$ (D) \\ Cleberton Correia Santos ${ }^{2}$ (D) \\ Néstor Antonio Heredia Zárate ${ }^{2}$ (D) \\ Maria do Carmo Vieira ${ }^{2}$ (D)
}

\begin{abstract}
The aim was to evaluate the effect of chicken manure and substrate liming in the Campomanesia xanthocarpa ('gabiroba') physiology, nutrition and growth. Five dosages of chicken manure $\left(0 ; 5 ; 10 ; 15\right.$ and $\left.20 \mathrm{Mg} \mathrm{ha}^{-1}\right)$ were studied without and with substrate liming. The treatments were arranged in a $5 \times 2$ factorial scheme, in a randomized block design with four replications. There was an improvement on the chemical attributes in the substrate and nutrients contained in the plants where liming was performed. The highest plant height of C. xanthocarpa occurred with liming and $9.03 \mathrm{Mg} \mathrm{ha}^{-1}$ of chicken manure. The diameters were liming-grown plants and $4.57 \mathrm{~mm}$ with $5 \mathrm{Mg}$ $\mathrm{ha}^{-1}$ of chicken manure. The photochemical efficiencies of PSII occurred in plants grown on liming substrate. It was concluded that C. xanthocarpa plants had their development optimizes with substrate liming and incorporation of $5 \mathrm{Mg} \mathrm{ha}^{-1}$ chicken manure.
\end{abstract}

Keywords: Gabiroba, organic residue, nutrient, soil correction, seedling production.

\section{INTRODUCTION AND OBJECTIVES}

Campomanesia xanthocarpa O. Berg (Myrtaceae) is a tree plant that can reach up to 15 meters high, popularly known as gabiroba, guabiroba, guavirova and tree of gabiroba; this arboreal species can be found in Argentina, Paraguay, Uruguay and Brazil, all the way from the Minas Gerais state to the Rio Grande do Sul state (Lorenzi, 2008). It has nutritional importance because its fruits have high levels of vitamins, fiber (Vallilo et al., 2008) and pectins (Barbieri et al., 2019). As medicinal it has anti-inflammatory (Klafke et al., 2016), antimicrobial, antioxidant (Capeletto et al., 2016), antiproliferative, trypanocidal (Salmazzo et al., 2019), activity and inhibitory effect on platelet aggregation (Otero et al., 2017).

However, despite having nutritional and medicinal properties, it was observed that there are still no well-defined cultural treatments for the cultivation of this species, making agronomic studies necessary, especially in the use of organic fertilizers and soil liming. Thus, proper correction to increase the availability of essential nutrients can become a method of accelerating the development of $C$. xanthocarpa, benefiting local populations and favoring the cultivation of the species.

In general, Brazilian soils have high levels of acidity and, consequently high levels of aluminum that can cause damage to the plant development, as well as low availability of nutrients in the soil, such as exchangeable calcium and magnesium (Torres et al., 2017). So, in this way, the use of substrate correction liming for the production of medicinal plants can be an appropriate practice. The adding of limestone to the substrate increases calcium and magnesium levels, decreases the substrate acidity by balancing reactions, and increases the activity of beneficial substrate bacteria (Rheinheimer et al., 2018; Auler et al., 2019), thus it accelerates the decomposition of waste, releasing mainly nitrogen and phosphorus (Soratto \& Cruscial, 2008), favoring plant growth.

${ }^{1}$ Universidade Federal da Grande Dourados (UFGD), Faculdade de Ciências Biológicas e Ambientais (FCBA), Dourados, MS, Brasil

${ }^{2}$ Universidade Federal da Grande Dourados (UFGD), Faculdade de Ciências Agrárias (FCA), Dourados, MS, Brasil 
Another practice used in the production of medicinal plants is the use of organic waste such as chicken manure. That when it is added to the soil it provides lots of carbon and nutrients, increasing microbiological activity in response to organic decomposition, consequently making nutrients more available for plant absorption, as well as contributing to aeration and water retention capacity (Silva et al., 2014).

The use of substrate liming for early growth of medicinal plants such as Campomanesia adamantium has shown excellent results (Melo et al., 2019), as well as the addition of chicken manure in the composition of substrates for early cultivation of C. xanthocarpa (Carnevali et al., 2015).

However in order to evaluate the response of the species to cultivation, one must know the species at a systemic level, that is, know the nutrition and physiology of the species. Thus, the use of methods that evaluate the physiological response, such as chlorophyll fluorescence (Zanandrea et al., 2006; Baker, 2008) and gas exchanges (Almeida et al., 2018), which evaluate the photosynthetic performance, are increasingly being used because they provide qualitative and quantitative information about the physiological condition, which give the systemic dimension of the organism in conjunction with plant nutrition.

Hence, the aim of this work was to evaluate the effect of chicken manure dosages and liming on the substrate for the nutrition, physiology and growth of C. xanthocarpa.

\section{MATERIALS AND METHODS}

\subsection{General conditions}

The experiment was developed with C. xanthocarpa in the Medicinal Plants Garden (22 $11^{\prime} 43.7^{\prime \prime} \mathrm{S}$ and $54^{\circ} 56^{\prime} 08.5^{\prime \prime} \mathrm{W}$, $452 \mathrm{~m}$ ), Federal University of Grande Dourados (UFGD), in Dourados, Mato Grosso do Sul (MS), Brazil. The region's climate according to the Köppen-Geiger classification is Aw (Alvares et al., 2013). The plants were cultivated in protected environment, with modular structure, prefab and with polyethylene side and top cover, besides of additional protection of $50 \%$ of irradiance with 'sombrite', with an average temperature of $28^{\circ} \mathrm{C}$, relative humidity of $70 \%$.

\subsection{Seed collection and seeding procurement}

The species was identified and exsiccate is deposited in the UFGD Herbarium, under $\mathrm{n}^{\circ} 4644$. The seeds were obtained from fruits (Access Register No. A9CDAAE - CGEN-MMA, $15 / 10 / 2018$ ) randomly collected from mother plants in the Assentamento Itamarati (22 $\left.11^{\prime} 14^{\prime \prime} \mathrm{S}, 55^{\circ} 35^{\prime} 07^{\prime \prime} \mathrm{W}, 538 \mathrm{~m}\right)$, in Ponta Porã - MS. Initial propagation was performed by sowing in 128-cell of polystyrene trays, filled with Tropstrato ${ }^{\circ}$ substrate, composed of pine bark, peat, vermiculite, simple superphosphate, potassium nitrate and products formulated by third parties, with a $\mathrm{pH}$ of 5.8 and electrical conductivity between 0.5 and $2.0 \mathrm{mS} \mathrm{cm}^{-1}$ and transplanted to plastic pots when seedlings reached an average height of $8 \mathrm{~cm}$ and average age of 3 months.

\subsection{Experimental drawing}

C. xanthocarpa plants were evaluated according to five dosages of semi-decomposed chicken manure $(0 ; 5 ; 10 ; 15$ and $\left.20 \mathrm{Mg} \mathrm{ha}^{-1}\right)$, calculated according to equation (1-2) without or with liming, calculated according to equation (3). The treatments were arranged in a $5 \times 2$ factorial scheme, in a randomized block design with four replications. The experimental unit consisted of four pots filled with $4 \mathrm{~kg}$ of Dystroferric Red Latosol (Oxisol), containing one plant each, totaling 160 plants.

(1) Megagrams per hectare of soil at a depth of $12 \mathrm{~cm}$ (pot): $M g h a^{-1}$ of soil in $12 \mathrm{~cm}$ depth $=\left(h a^{-1} \times P d\right) \times S d$ $\mathrm{Mg} \mathrm{ha} \mathrm{a}^{-1}$ of soil in $12 \mathrm{~cm}$ depth=1.44 $\mathrm{Mg} \mathrm{ha}^{-1}$

$\mathrm{ha}^{-1}=10000 \mathrm{~m}^{2}$;

Pot depth $(\mathrm{Pd})=0.12 \mathrm{~m}$;

Soil density $(\mathrm{Sd})=1200 \mathrm{~kg} \mathrm{~m}^{-3}$.

(2) Dosage of chicken manure in the pot:

Chicken manure $_{\mathrm{Mgha}^{-1}}=\frac{\left(\text { Dosage } \times \mathrm{Mg} \mathrm{h} \mathrm{a}^{-1} \text { in } 12 \mathrm{~cm} \mathrm{depth}\right)}{\text { Soil in the pot }}$

Dosage: 5, 10, 15 and $20 \mathrm{Mg} \mathrm{ha}^{-1}$;

$\mathrm{Mg} \mathrm{ha}^{-1}$ in $12 \mathrm{~cm}$ depth $=1.44 \mathrm{Mg} \mathrm{ha}^{-1}$;

Megagrams of soil in the pot $=0,004 \mathrm{Mg}$.

(3) Sousa \& Lobato, 2004.

$$
L R_{M g h a^{-1}}=\frac{\left[C E C \times(V 2-V 1) \times\left(\frac{100}{R T N P}\right)\right.}{100}
$$

$\mathrm{LR}=$ Limestone requirement, in $\mathrm{Mg} \mathrm{ha}^{-1}$;

$\mathrm{CEC}=$ Cation exchange capacity;

$\mathrm{V} 2=$ Base saturation desired (60\%);

$\mathrm{V} 1$ = Current base saturation of soil;

RTNP = Relative Total Neutralization Power.

The clayey Oxisol, with density of $1200 \mathrm{~kg} \mathrm{~m}^{-3}$ (Santos et al., 2013), was collected from the Cerrado remnant area and it presented the following chemical attributes: 
$\mathrm{pH}$ in $\mathrm{CaCl}_{2}=4.57 ; \mathrm{P}\left(\mathrm{mg} \mathrm{dm}^{-3}\right)=3.60 ; \mathrm{K}, \mathrm{Ca}, \mathrm{Mg}, \mathrm{Al}$, $\mathrm{H}+\mathrm{Al}, \mathrm{SB}$ and CTC $\left(\mathrm{cmol}_{c} \mathrm{dm}^{-3}\right)=0.08 ; 1.46 ; 0.41 ; 1.20$; $3.63 ; 1.95$ and 5.57 , respectively; $\mathrm{V}(\%)=34.9$; organic matter $=9.58 \mathrm{~g} \mathrm{dm}^{-3} ; \mathrm{Cu}, \mathrm{Mn}, \mathrm{Fe}$ and $\mathrm{Zn}\left(\mathrm{mg} \mathrm{dm}^{-3}\right)=3.64$; $16.12 ; 31.67$ and 0.70 , respectively. The semi-decomposed chicken manure was purchased from an aviary located on the midwest region of Brazil with the following chemical attributes: macronutrients $\left(\mathrm{g} \mathrm{kg}^{-1}\right) \mathrm{N}=23.90 ; \mathrm{P}=15.36$; $\mathrm{K}=20.00 ; \mathrm{Ca}=19.15 ; \mathrm{Mg}=6.95 ; \mathrm{S}=18.65 ; \mathrm{C}=260$; $\mathrm{OM}=447.00 ; \mathrm{C} / \mathrm{N}$ ratio $=10.87 ;$ micronutrients $\left(\mathrm{mg} \mathrm{kg}^{-1}\right)$ $\mathrm{Cu}=130 ; \mathrm{Zn}=136 ; \mathrm{Fe}=950 ; \mathrm{Mn}=840 ; \mathrm{B}=4.5$; humidity: $11 \%$ and $\mathrm{pH}=7.50$. Dolomitic limestone $\left(\mathrm{CaCO}_{3} \cdot \mathrm{MgCO}_{3}\right)$ with PRNT $80 \%$ was used at dosage of $1.74 \mathrm{Mg} \mathrm{ha}^{-1}$, there is calculated according to equation (3), and chicken manure was incorporated in corresponding plots, 30 days before seedling transplantation. After the implementation of experiment, daily irrigations were performed to maintain $70 \%$ of the substrate field capacity and spontaneous plant uprooting when necessary.

\subsection{Evaluated characteristics}

During the cultivation cycle, between 15 and 165 days after transplanting (DAT), every 15 days the plant heights were measured using a ruler graduated in $\mathrm{mm}$ and the diameter of the stem using a digital caliper. Between 30 and 150 DAT, every 30 days, in the morning period (between 8 and 10h) the parameters of chlorophyll fluorescence were measured by photochemical quantum efficiency of photosystem II $\left(F_{v} / F_{\mathrm{m}}\right)$ and the conversion of absorbed energy $\left(F_{v} / F_{0}\right)$. For this, the third fully expanded leaf contact from the apex of each plant was subjected to dark conditions using leaf clips for 30 minutes under flash $1500 \mu \mathrm{mol} \mathrm{m}^{-2} \mathrm{~s}^{-1}$. Readings were taken with a portable fluorometer (OPTI-SCIENCES Chlorophyll Fluorometer, Hudson, USA). And at the same time, chlorophyll index and chlorophyll $a$ e $b$, indices were also determined using a portable CFL-1030 clorofiLOG Falker.

Every 30 days, from 60 to $150 \mathrm{DAT}$, the photosynthesis rate $A$, intercellular $\mathrm{CO}_{2}$ concentration - $C_{i}$, stomatal conductance $g s$ and transpiration rate - $E$, using a portable photosynthesis meter (IRGA - Ifra Red Gas Analyzer) (Model ADC BioScientific Ltd.), taking the evaluations in the morning, under averages of $423 \mu \mathrm{mol} \mathrm{mol}^{-1}$ of external $\mathrm{CO}_{2}$ concentration (Cref) and $360.3 \mu \mathrm{mol} \mathrm{m}^{-2} \mathrm{~s}^{-1}$ of photosynthetically active radiation (PAR).

After 180 DAT, all plants were harvested and the length of largest root was evaluated; leaf and root areas with area integrator (LI-COR, $3100 \mathrm{C}$ - Area Meter, in Nebraska, USA). To obtain the dry masses, the leaves, stems, roots were conditioned in a forced air circulation oven $\left(60 \pm 5^{\circ} \mathrm{C}\right)$, until constant mass, were weighed in a precision scale.
With the biomass data, height/diameter ratio, shoot, and root ratio data, the Dickson Quality Index (DQI) was calculated (Dickson et al., 1960).

From the dry material, the macro and micronutrient contents of the aerial parts were quantified. This material was digested by the nitro-perchloric digestion mixture (2:1), to obtain an extract, in which the total leaf concentrations were determined to $\mathrm{P}, \mathrm{K}, \mathrm{Ca}, \mathrm{Mg}, \mathrm{Cu}, \mathrm{Mn}, \mathrm{Fe}, \mathrm{Zn}$ and total leaf concentrations of $\mathrm{N}$, sulfuric digestion and methodology described by Malavolta (2006) were used. The chemical attributes of the substrates were determined according to Silva (2009) methodology from samples collected at the time of plant harvest.

\subsection{Statistical analysis}

The data were submitted to analysis of variance (ANOVA) and when significant by the $F$ test $(\mathrm{p}<0.05)$ the measures were submitted to regression analysis for chicken manure dosages and Student's t-test for liming $(\mathrm{p}<0.05)$. Data taken throughout the cycle were analyzed as time subdivided plots and submitted to $\mathrm{F}$ test and regression $(\mathrm{p}<0.05)$.

\section{RESULTS}

\subsection{Chemical attributes of substrates}

There was an improvement in chemical attributes when compared to soil analysis at the beginning of experiment (Table 1). So that, after the cultivation cycle, there was an average increase of $21 \%$ in pH, $72 \% \mathrm{OM}, 24 \% \mathrm{P}, 50 \% \mathrm{~K}, 42 \%$ $\mathrm{Ca}, 356 \% \mathrm{Mg}, 40 \% \mathrm{Cu}, 87 \% \mathrm{Mn}, 23 \% \mathrm{Fe}, 131 \% \mathrm{Zn}, 182 \% \mathrm{SB}$, $44 \% \mathrm{CEC}$ and $94 \% \mathrm{~V} \%$, while $\mathrm{Al}$ content decreased $90 \%$ over the cycle, thus reducing the potential acidity $(\mathrm{H}+\mathrm{Al})$ in $31 \%$. However, despite the increase in $\mathrm{OM}, \mathrm{P}$ and $\mathrm{Zn}$ throughout the cycle were not influenced by the factors under study, with averages of $16.5 \mathrm{~g} \mathrm{dm}^{-3}, 4.46$ and $1.62 \mathrm{mg} \mathrm{dm}^{-3}$, respectively.

The chemical attributes of $\mathrm{V} \%$ and CEC were influenced by the interaction of the factors under study. $\mathrm{Cu}, \mathrm{Mn}$ and Fe were influenced by the isolated factors, while $\mathrm{pH}, \mathrm{K}, \mathrm{Ca}$, $\mathrm{Mg}, \mathrm{Al}$, potential acidity $(\mathrm{H}+\mathrm{Al})$ and $\mathrm{SB}$ were influenced only by the liming of the substrates (Table 1).

In general, the attributes involving base saturation $(\mathrm{pH}, \mathrm{Ca}, \mathrm{Mg}, \mathrm{SB})$ were higher in the liming substrates, highlighting the absence of aluminum in these substrates (Table 1). While, the highest availability of $\mathrm{Cu}, \mathrm{Mn}$ and $\mathrm{Fe}$ and $\mathrm{K}$ micronutrients occurred in substrates without liming in addition to the higher $\mathrm{Al}$ content and potential acidity $(\mathrm{H}+\mathrm{Al})$ (Table 1$)$. 
Table 1. Chemical attributes of the substrate without and with liming for the cultivation of C. xanthocarpa.

\begin{tabular}{cccc}
\multirow{2}{*}{ Chemical attributes } & \multicolumn{2}{c}{ Liming } & \multirow{2}{*}{ C.V. (\%) } \\
\cline { 2 - 3 } & Without & With & \\
\hline $\mathrm{pH} \mathrm{CaCl}$ & & \\
\cline { 2 - 3 }$\left(\mathrm{cmol}_{\mathrm{c}} \mathrm{dm}^{-3}\right)$ & $0.79 \mathrm{~b}$ & $6.26 \mathrm{a}$ & 3.30 \\
$\mathrm{Ca}\left(\mathrm{cmol}_{\mathrm{c}} \mathrm{dm}^{-3}\right)$ & $2.81 \mathrm{~b}$ & $4.24 \mathrm{a}$ & 8.70 \\
$\mathrm{Mg}\left(\mathrm{cmol}_{\mathrm{c}} \mathrm{dm}^{-3}\right)$ & $1.09 \mathrm{~b}$ & $2.63 \mathrm{a}$ & 8.00 \\
$\mathrm{Al}\left(\mathrm{cmol}_{\mathrm{c}} \mathrm{dm}^{-3}\right)$ & $0.29 \mathrm{a}$ & $0.00 \mathrm{~b}$ & 63.90 \\
$\mathrm{H}+\mathrm{Al}\left(\mathrm{cmol}_{\mathrm{c}} \mathrm{dm}^{-3}\right)$ & $3.02 \mathrm{a}$ & $1.97 \mathrm{~b}$ & 4.70 \\
\hline $\mathrm{SB}\left(\mathrm{cmol}_{\mathrm{c}} \mathrm{dm}^{-3}\right)$ & $4.03 \mathrm{~b}$ & $7.00 \mathrm{a}$ & 8.09 \\
$\mathrm{Cu}\left(\mathrm{mg} \mathrm{dm}^{-3}\right)$ & $5.35 \mathrm{a}$ & $4.88 \mathrm{~b}$ & 7.90 \\
$\mathrm{Mn}\left(\mathrm{mg} \mathrm{dm}^{-3}\right)$ & $33.06 \mathrm{a}$ & $27.31 \mathrm{~b}$ & 12.30 \\
$\mathrm{Fe}\left(\mathrm{mg} \mathrm{dm}^{-3}\right)$ & $43.88 \mathrm{a}$ & $33.88 \mathrm{~b}$ & 16.00
\end{tabular}

Means followed by the same letters in the lines do not differ by Student's t-test $(\mathrm{p}>0.05)$. Hydrogen potential $(\mathrm{pH})$, potential acidity $(\mathrm{H}+\mathrm{Al})$, sum of bases $(\mathrm{SB})$. C.V. (\%) - coefficient of variation.

(a)

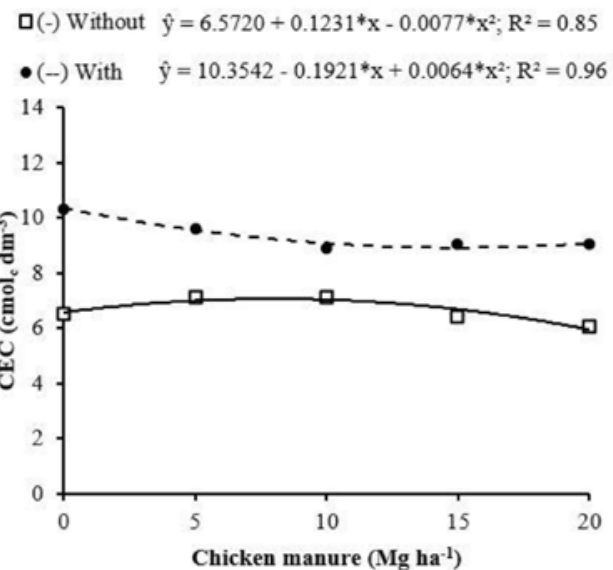

(c)

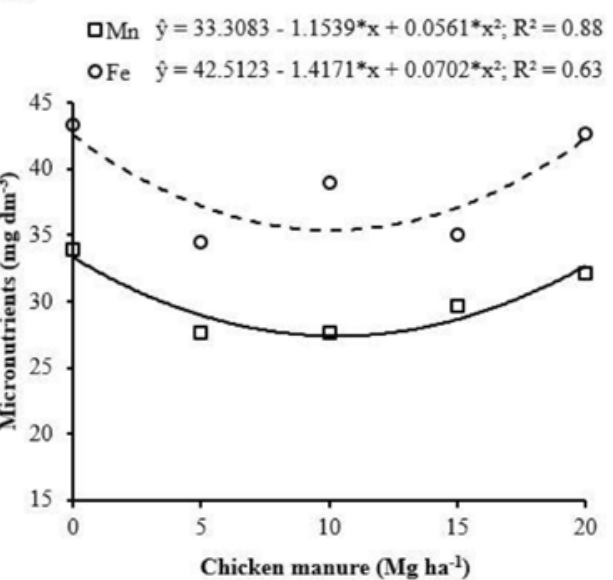

The highest CEC occurred in the substrate that was liming, with $10.33 \mathrm{cmol} \mathrm{dm}^{-3}$ without the incorporation of chicken manure (Fig. 1a), while the smallest $\left(8.91 \mathrm{cmol} \mathrm{dm}^{-3}\right)$ under $14.9 \mathrm{Mg} \mathrm{ha}^{-1}$ on substrates that were liming. Regarding the substrate without liming, the highest CEC $\left(7.06 \mathrm{cmol}_{\mathrm{c}} \mathrm{dm}^{-3}\right)$ occurred with the incorporation of 7.9 $\mathrm{Mg} \mathrm{ha}^{-1}$ of chicken manure and the lowest (6.06) under $20 \mathrm{Mg} \mathrm{ha}^{-1}$ (Fig. 1a).

Regarding base saturation (V\%), the highest value (78.2\%) occurred in the substrate with incorporation of $15 \mathrm{Mg} \mathrm{ha}^{-1}$ of chicken manure and liming (Fig. 1b). Similarly, V\% (69.32) of substrate without liming was higher at the same dosage. While, the lowest percentages were observed in substrates without chicken manure, regardless of liming (Fig. 1b).

The highest availability of Fe, Mn (Fig. 1c) and $\mathrm{Cu}$ (Fig. 1d) micronutrients occurred in substrates without $(43.2 ; 33.9$ and $5.5 \mathrm{mg} \mathrm{dm}^{-3}$, respectively) and with $20 \mathrm{Mg} \mathrm{ha}^{-1}$ (42.7; 32.1 and $5.2 \mathrm{mg} \mathrm{dm}^{-3}$, respectively) of chicken manure (Fig. 1c and 1d).

(b)

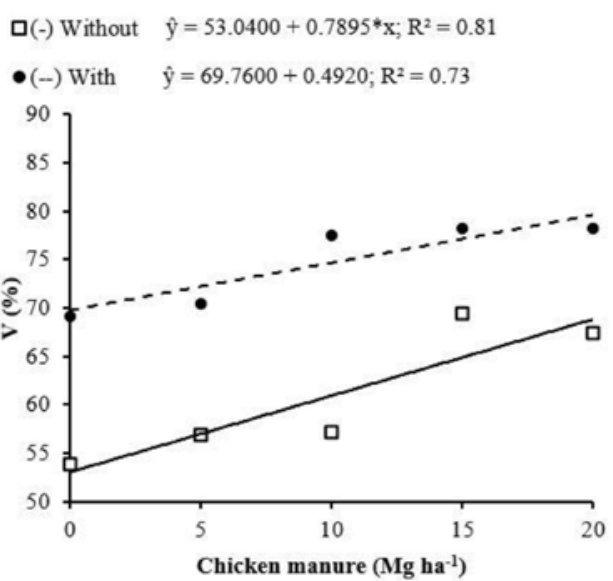

(d)

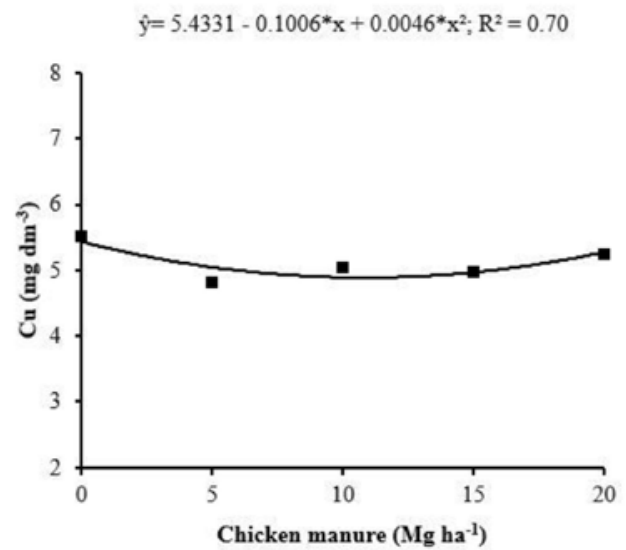

Figure 1. (a) Cationic exchange capacity (CEC) and (b) bases saturation (V\%) of the substrates added dosages of chicken manure and liming. (c) Micronutrients $(\mathrm{Fe}, \mathrm{Mn})$ and (d) $\mathrm{Cu}$ of the substrates added dosages of chicken manure. ${ }^{*}(\mathrm{p}<0.05)$ 


\subsection{Nutritional status of plants}

The N, P, Ca, $\mathrm{Cu}, \mathrm{Mn}$ and $\mathrm{Zn}$ contents of the aerial part were influenced only by liming of the substrate, with an increase of $48.5 \%(\mathrm{~N}) ; 73.1 \%(\mathrm{P})$ and $11.0 \%(\mathrm{Ca})$ compared to nutrients from plants grown without liming process (Table 2). Controversially, the highest levels of $\mathrm{Cu}$, $\mathrm{Mn}$ and $\mathrm{Zn}$ foliar occurred in plants cultivated under the substrate without liming, with an increase of 119.2; 50.9 and $44.4 \%$, respectively, regarding to plants in substrate with liming. Only foliar Mg and Fe were not influenced by factors under study.

Table 2. Macro and micronutrients in leaves of C. xanthocarpa cultivated as a function of liming.

\begin{tabular}{|cccc}
\multirow{2}{*}{ Nutrients } & \multicolumn{2}{c}{ Liming } & \multirow{2}{*}{ C.V. (\%) } \\
\cline { 2 - 3 } & Without & With & \\
\hline $\mathrm{N}\left(\mathrm{g} \mathrm{kg}^{-1}\right)$ & $12.25 \mathrm{~b}$ & $18.20 \mathrm{a}$ & 20.40 \\
\hline $\mathrm{P}\left(\mathrm{g} \mathrm{kg}^{-1}\right)$ & $1.56 \mathrm{~b}$ & $2.70 \mathrm{a}$ & 26.95 \\
\hline $\mathrm{Ca}\left(\mathrm{g} \mathrm{kg}^{-1}\right)$ & $10.16 \mathrm{~b}$ & $11.28 \mathrm{a}$ & 14.92 \\
\hline $\mathrm{Mg}\left(\mathrm{g} \mathrm{kg}^{-1}\right)$ & $3.40 \mathrm{a}$ & $3.64 \mathrm{a}$ & 21.91 \\
\hline $\mathrm{Cu}\left(\mathrm{mg} \mathrm{kg}^{-1}\right)$ & $11.84 \mathrm{a}$ & $5.40 \mathrm{~b}$ & 53.17 \\
\hline $\mathrm{Mn}\left(\mathrm{mg} \mathrm{kg}^{-1}\right)$ & $214.27 \mathrm{a}$ & $141.98 \mathrm{~b}$ & 17.38 \\
\hline $\mathrm{Fe}\left(\mathrm{mg} \mathrm{kg}^{-1}\right)$ & $397.99 \mathrm{a}$ & $405.91 \mathrm{a}$ & 56.17 \\
\hline $\mathrm{Zn}\left(\mathrm{mg} \mathrm{kg}^{-1}\right)$ & $35.02 \mathrm{a}$ & $24.25 \mathrm{~b}$ & 19.98 \\
\hline
\end{tabular}

Means followed by the same letters in the lines do not differ by Student's t-test ( $p>0.05)$. C.V. (\%) - coefficient of variation.

The $\mathrm{K}$ content was influenced by the factor interaction under study, with a maximum content of $13.76 \mathrm{~g} \mathrm{~kg}^{-1}$ in plants grown with $20 \mathrm{Mg} \mathrm{ha}^{-1}$ of chicken manure, and substrate liming (Fig. 2). On the other hand, the data without liming did not fit the mathematical models used, obtaining an average of $11.16 \mathrm{~g} \mathrm{~kg}^{-1}$.

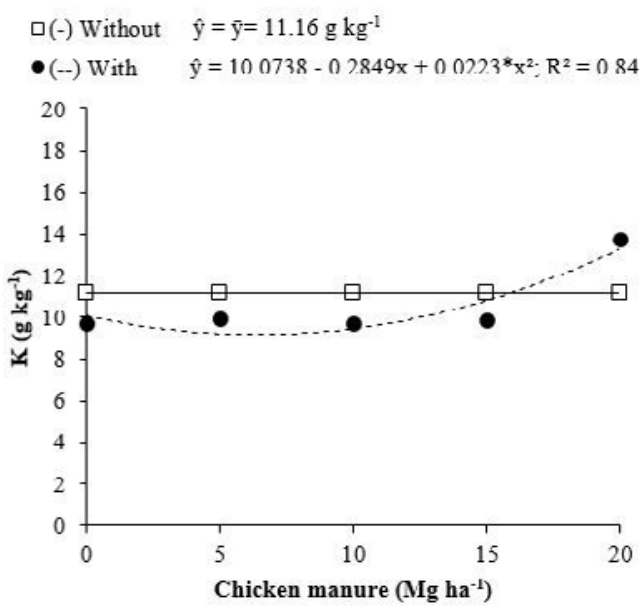

Figure 2. Potassium (K) content in leaves of C. xanthocarpa cultivated with chicken manure and liming. ${ }^{*}(\mathrm{p}<0.05)$

\subsection{Physiological responses}

The chlorophyll index was influenced by chicken manure and evaluation periods, as the maximum index (31.7) occurred in plants grown under $5 \mathrm{Mg} \mathrm{ha}^{-1}$ of chicken manure substrate at $150 \mathrm{DAT}$ (Fig. 3a), presenting curve with increasing rates, starting at 79.1 DAT. As for the chlorophyll $a$, it was observed interaction in liming and chicken manure, with maximum index (21.3) in substrate without liming, with incorporation of $20 \mathrm{Mg} \mathrm{ha}^{-1}$ of chicken manure (Fig. 3b), while with liming there was no adjustment of model used, with an average of 21.9 (Fig. 3b). The chlorophyll $b$ was influenced by liming and evaluation periods, where the maximum index (6.52) in plants grown on limed substrate at 150 DAT (Fig. 3c). There was also interaction between chicken manure and evaluation periods, with a maximum index in the range of 6.0-7.0 with incorporation of 5,15 and $20 \mathrm{Mg} \mathrm{ha}^{-1}$ of chicken manure, they presented curves with increasing rates, starting at 82.3; 79.5 and 54.9 DAT, respectively (Fig. 3d). 
(a)

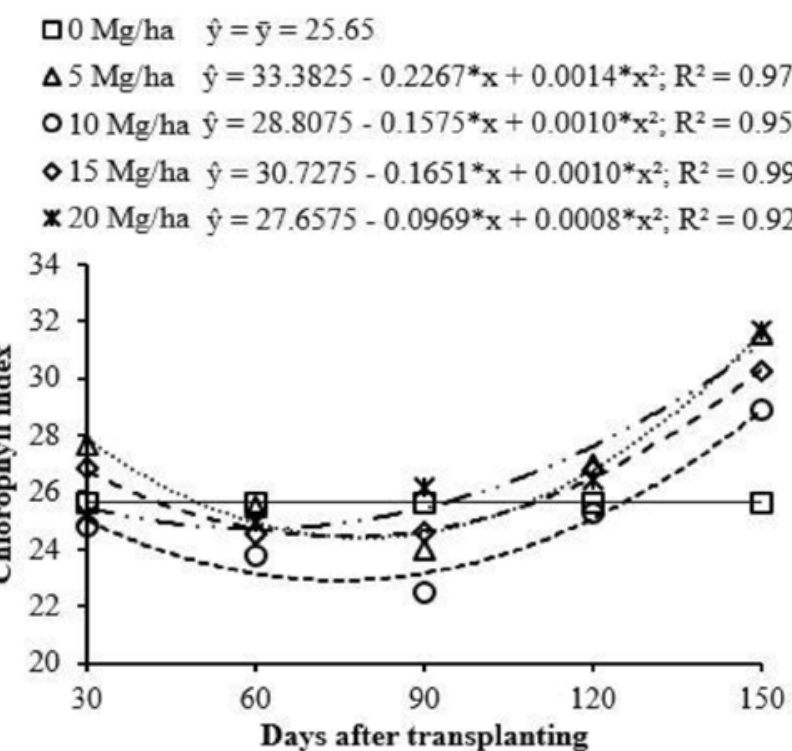

(c)

口(-) Without $\hat{y}=6.7070-0.0591 * x+0.0003 * x^{2} ; R^{2}=0.98$
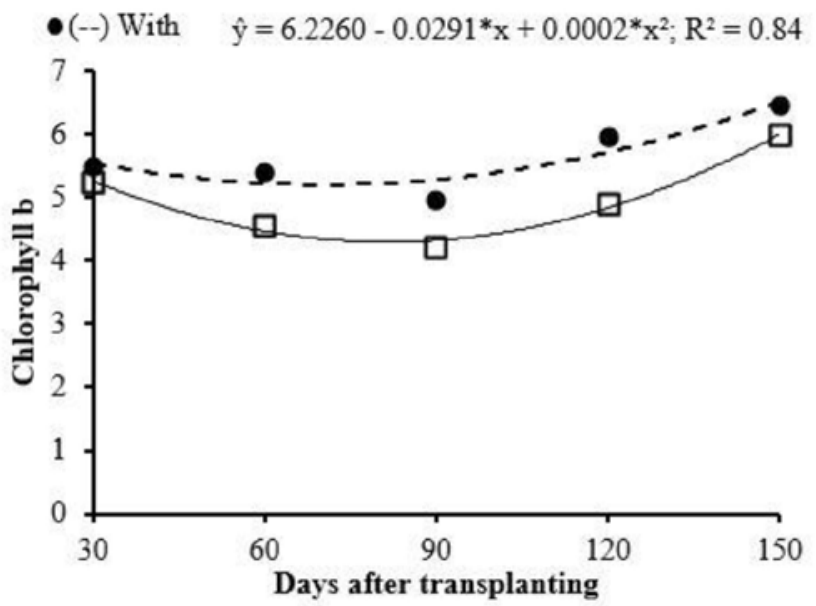

(b)

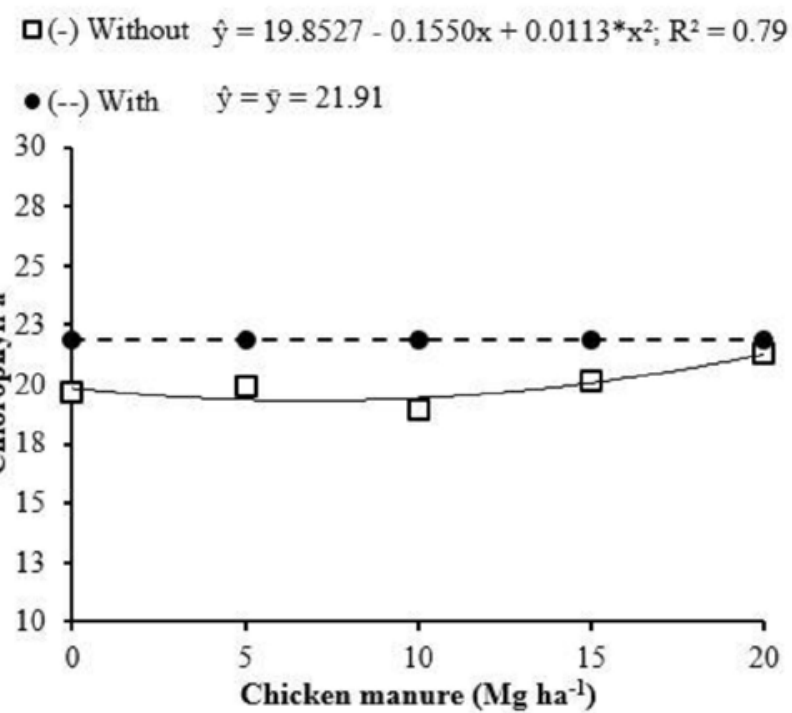

(d)

$$
\begin{aligned}
& \square 0 \mathrm{Mg} / \mathrm{ha} \quad \hat{\mathrm{y}}=\overline{\mathrm{y}}=5.17 \\
& \Delta 5 \mathrm{Mg} / \mathrm{ha} \quad \hat{\mathrm{y}}=8.0900-0.0909 * \mathrm{x}+0.0005^{*} \mathrm{x}^{2} ; \mathrm{R}^{2}=0.86 \\
& 010 \mathrm{Mg} / \mathrm{ha} \hat{\mathrm{y}}=6.4200-0.0478 * \mathrm{x}+0.0003 * \mathrm{x}^{2} ; \mathrm{R}^{2}=0.85 \\
& \diamond 15 \mathrm{Mg} / \mathrm{ha} \hat{\mathrm{y}}=6.8550-0.0501 * \mathrm{x}+0.0003 * \mathrm{x}^{2} ; \mathrm{R}^{2}=0.92 \\
& \text { * } 20 \mathrm{Mg} / \mathrm{ha} \hat{\mathrm{y}}=5.4800-0.0208 \mathrm{x}+0.00001 * \mathrm{x}^{2} ; \mathrm{R}^{2}=0.98
\end{aligned}
$$

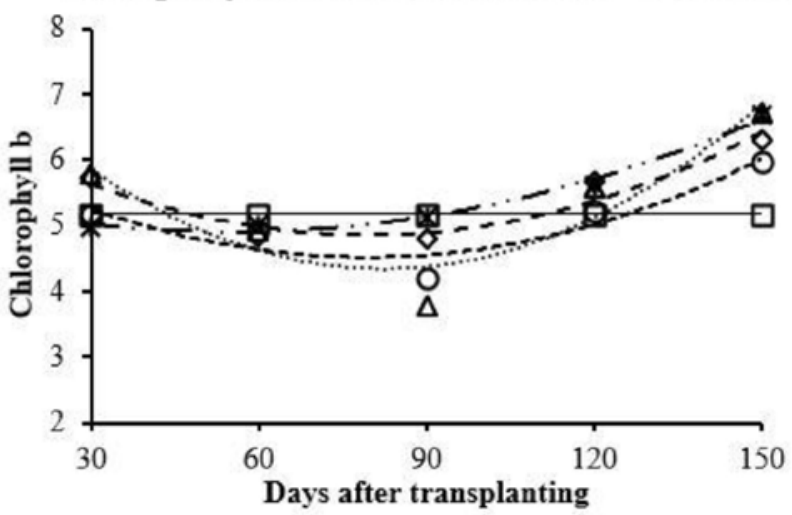

Figure 3. (a) Chlorophyll index in C. xanthocarpa plants grown on substrate with dosage of chicken manure throughout the cultivation cycle; (b) Chlorophyll $a$ as a function of liming and dosage of chicken manure, (c) Chlorophyll b as a function of liming and (d) dosage of chicken manure with times of evaluations. ${ }^{*}(\mathrm{p}<0.05)$

The photochemical efficiencies of PS II $\left(F_{v} / F_{m}\right)$ and absorbed energy conversion of $\left(F_{v} / F_{0}\right)$ were influenced by the interaction of times and liming on the substrate, where the highest photochemical indicators $(0.749$ and 3.01, respectively) occurred in plants grown on the substrate with liming at 150 DAT (Fig. 4a and 4b). Both characteristics showed increasing curves starting at 83.8 DAT (Fig. 4b).

In general, chicken manure contributes little to gas exchange of C. xanthocarpa seedlings, that is, the effect of days after transplanting and liming separately. The intercellular $\mathrm{CO}_{2}$ concentration $\left(C_{i}\right)$ was influenced by interaction of the evaluation time and liming, with higher $C_{\mathrm{i}}$ of the plants in substrate without liming at 150 DAT, which presented increasing curves (Fig. 4c), and lower value at $102 \mathrm{DAT}$ in liming substrate. Regarding the evaluation period, it was observed a maximum $A(4.26 \mu \mathrm{mol}$ of $\left.\mathrm{CO}_{2} \mathrm{~m}^{-2} \mathrm{~s}^{-1}\right)$ and $E\left(2.34 \mathrm{mmol}\right.$ of $\left.\mathrm{H}_{2} \mathrm{O} \mathrm{m}^{-2} \mathrm{~s}^{-1}\right)$ were found at 77.8 and 102.3 DAT (Fig. $4 \mathrm{~d}$ and $4 \mathrm{e}$ ). The maximum $g s$ was of $0.065 \mathrm{~mol} \mathrm{~m}^{-2} \mathrm{~s}^{-1}$ at 150 DAT (Fig. 4f). 
(a)

$\square(-)$ Without $\hat{\mathrm{y}}=0.8149-0.0040^{*} \mathrm{x}+0.000024 * \mathrm{x}^{2} ; \mathrm{R}^{2}=0.88$

$\bullet(--)$ With $\quad \hat{y}=0.7673-0.0020 * x+0.000012 * x^{2} ; R^{2}=0.80$

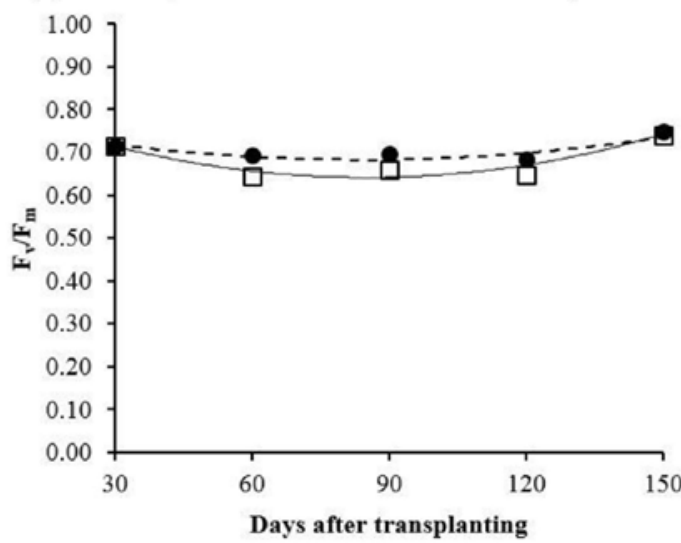

(c)

$\square(-)$ Without $\hat{y}=402.9062-2.6389 * x+0.0138 * x^{2} ; R^{2}=0.99$

$\bullet(-)$ With $\quad \hat{y}=432.3962-3.5840 * x+0.0187 * x^{2} ; R^{2}=0.78$

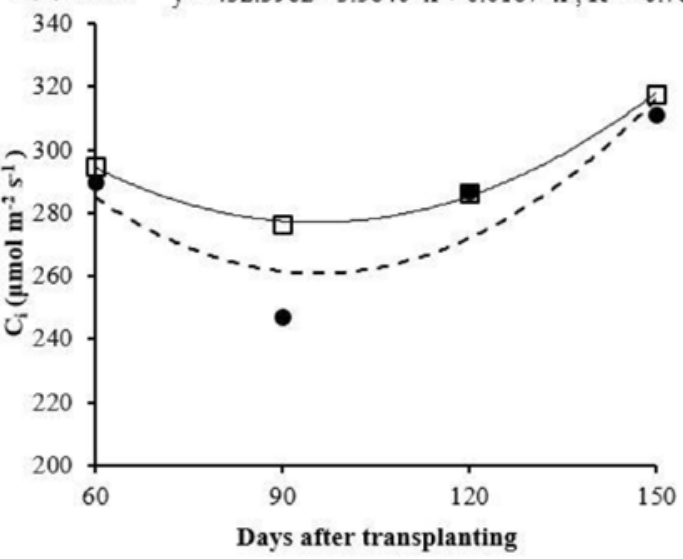

(e)

OE $\hat{y}=0.1097-0.0011^{*} x+0.000005^{*} x^{2} ; R^{2}=0.99$

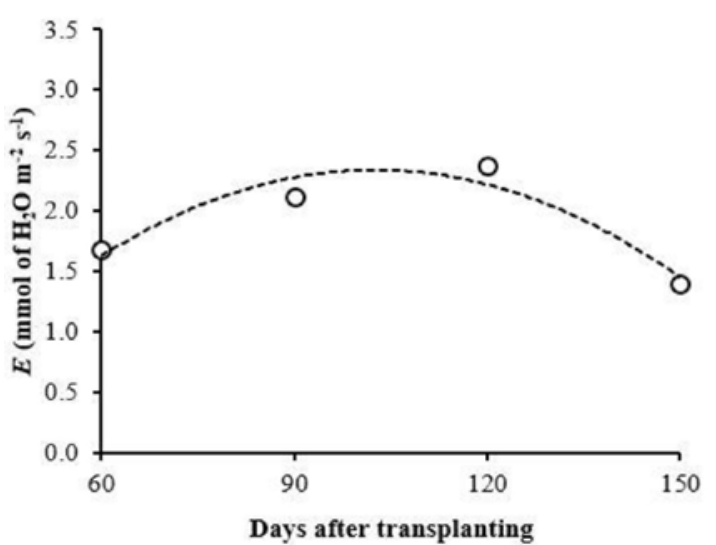

(b)

$\square(-)$ Without $\hat{y}=3.480-0.0390 * x+0.0002 * x^{2} ; R^{2}=0.93$

$\bullet(--)$ With $\quad \hat{y}=3.1746-0.0241^{*} \mathrm{x}+0.0001^{*} \mathrm{x}^{2} ; \mathrm{R}^{2}=0.85$

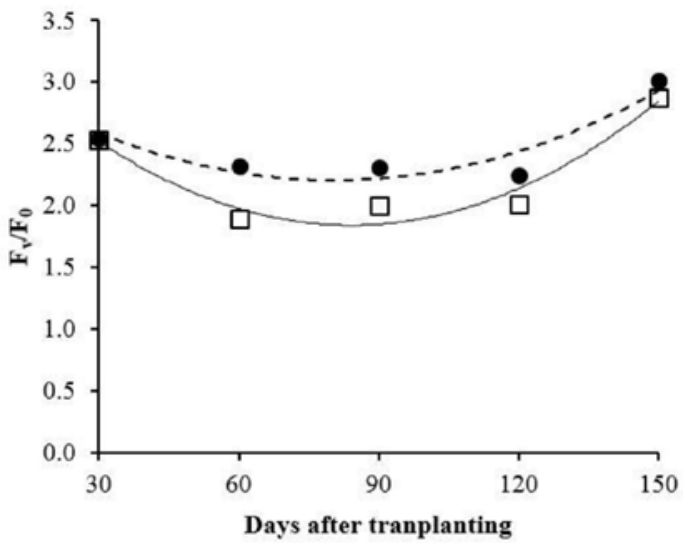

(d)

ㅁ. $\hat{y}=3.1661+0.0280 x+0.0001 * x^{2} ; R^{2}=0.72$

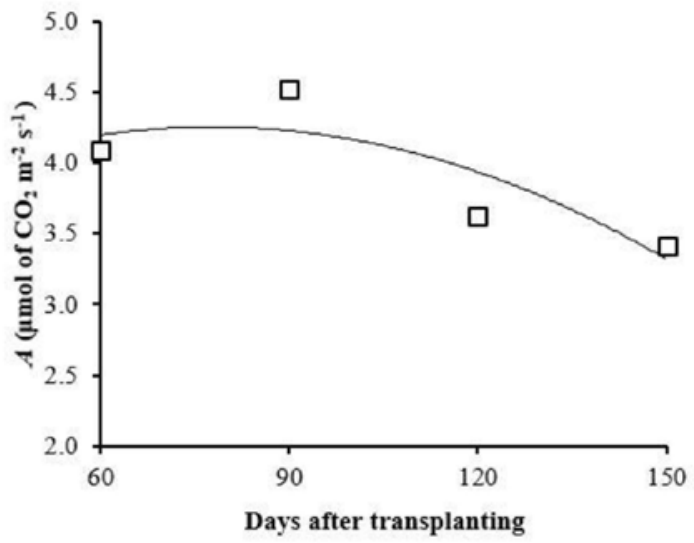

(f)

Ogs $\hat{y}=0.1097-0.0011 * x+0.000005 x^{2} ; R^{2}=0.99$

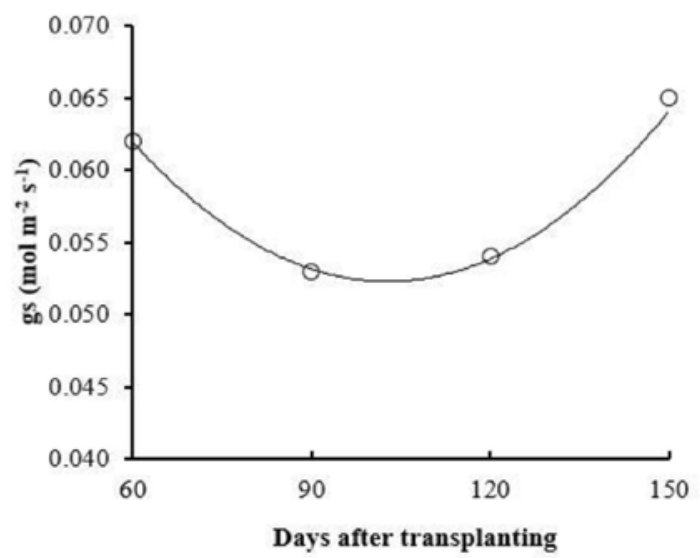

Figure 4. (a) Photochemical efficiency of photosystem II $\left(\mathrm{F}_{\mathrm{v}} / \mathrm{F}_{\mathrm{m}}\right)$, (b) absorbed energy conversion efficiency $\left(\mathrm{F}_{\mathrm{v}} / \mathrm{F}_{0}\right)$, and (c) intercellular $\mathrm{CO}_{2}$ concentration $\left(C_{\mathrm{i}}\right)$ of $C$. xanthocarpa plants with liming throughout the cultivation cycle. (d) Photosynthetic rate $=A$, (e) transpiration rate $=E$ and $(\mathrm{f})=$ stomatal conductance $(g s)$ of $C$. xanthocarpa plants throughout the cultivation cycle. ${ }^{*}(\mathrm{p}<0.05)$ 
In addition, we verifiy that transpiration rate $(E)$, stomatal conductance $(g s)$ and photosynthesis rate $(A)$ were only influenced by the evaluation time and liming. The highest values of gas exchange occurred in plants grown on liming substrate (Table 3).

Table 3. Transpiration rate $(E)$, stomatal conductance $(g s)$, photosynthetic rate $(A)$ of $C$. xanthocarpa plants grown on substrate without or with liming.

\begin{tabular}{cccc} 
& $E$ & $g_{s}$ & $A$ \\
\cline { 2 - 4 } Liming & $\begin{array}{c}\left(\mathbf{m m o l ~ o f ~ H}_{2} \mathbf{O}\right. \\
\left.\mathbf{m}^{-2} \mathbf{~ s}^{-1}\right)\end{array}$ & $\begin{array}{c}\left(\mathrm{mol} \mathrm{m}^{-2}\right. \\
\left.\mathrm{s}^{-1}\right)\end{array}$ & $\begin{array}{c}\left(\mu \mathrm{mol} \mathrm{of} \mathrm{CO}_{2}\right. \\
\left.\mathbf{m}^{-2} \mathrm{~s}^{-1}\right)\end{array}$ \\
Without & $1.78 \mathrm{~b}$ & $0.055 \mathrm{~b}$ & $3.53 \mathrm{~b}$ \\
With & $2.00 \mathrm{a}$ & $0.062 \mathrm{a}$ & $4.30 \mathrm{a}$ \\
C.V. $(\%)$ & 22.93 & 30.27 & 23.40 \\
\hline
\end{tabular}

Means followed by the same letters in the column do not differ by Student's t-test probability ( $p>0.05)$. C.V. (\%) - coefficient of variation.

(a)

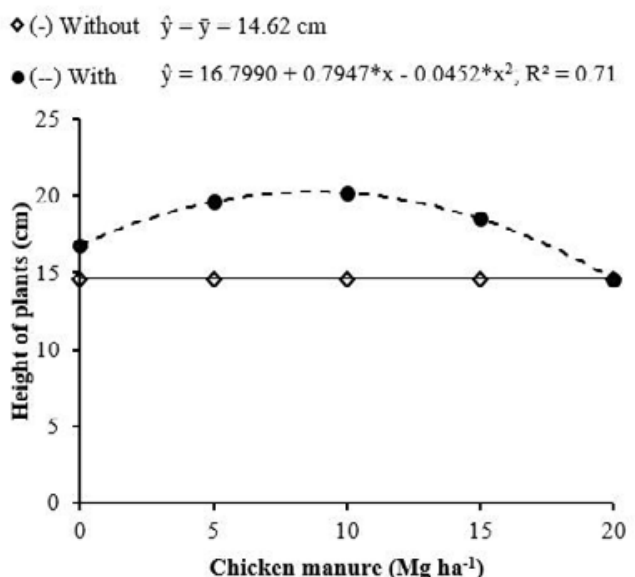

\subsection{Growth indicators}

The plant height was influenced by interaction of chicken manure and liming, with a maximum height of $19.46 \mathrm{~cm}$ when cultivated on corrected substrate, with $9.03 \mathrm{Mg} \mathrm{ha}^{-1}$ of chicken manure; however the data without liming did not fit the mathematical models, with an average of $14.62 \mathrm{~cm}$ (Fig. 5a). Also, it was verified the interaction of evaluation and liming times, with higher height of $(27.82 \mathrm{~cm})$ in liming substrate, at 165 DAT (Fig. 5b).

The collar diameter of plants was influenced by interactions between substrate correction and evaluation times, and by chicken manure dosages and DAT. The largest diameters were of 4.51 of the plants cultivated with liming (Fig. 6a) and 4.57 $\mathrm{mm}$ with $5 \mathrm{Mg} \mathrm{ha}^{-1}$ of chicken manure (Fig. 6b), respectively, both at 165 DAT.

(b)

$\square(-)$ Without $\hat{y}=7.9942+0.0737 * x ; R^{2}=0.96$

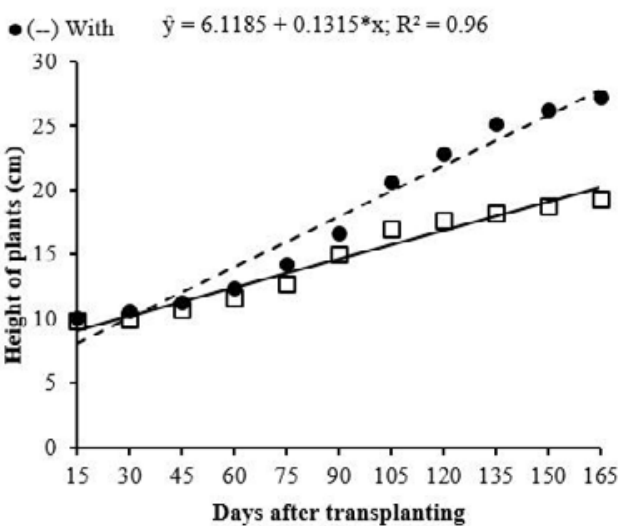

Figure 5. Height of plants of C. xanthocarpa grown on substrate without or with liming and chicken manure (a) and without and with liming throughout the cultivation cycle $(\mathrm{b}) .{ }^{*}(\mathrm{p}<0.05)$

(a)

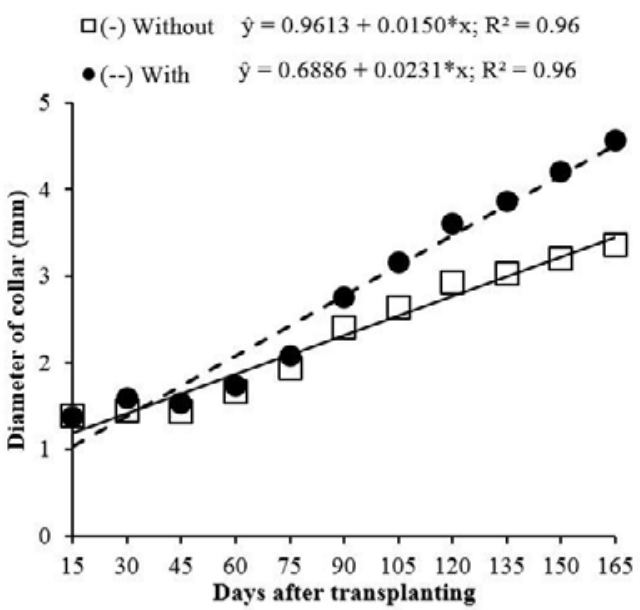

(b)

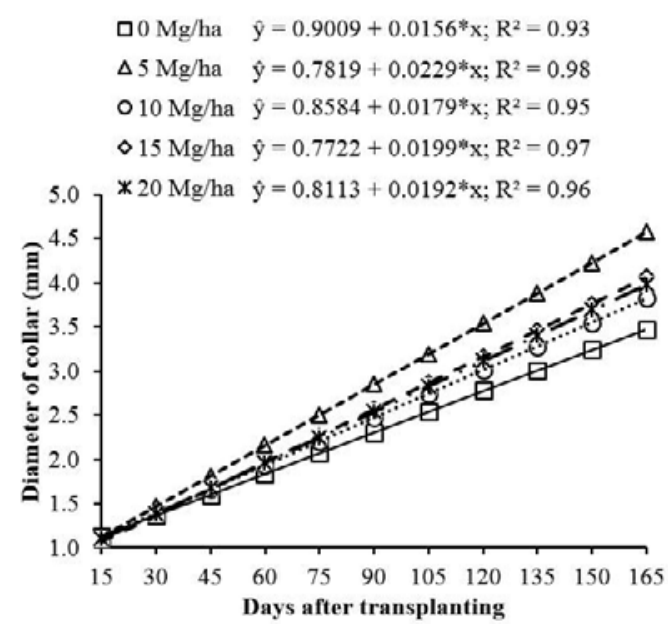

Figure 6. Diameter of collar of C. xanthocarpa grown on substrate without and with liming (a) and chicken manure (b), throughout the cultivation cycle. ${ }^{*}(\mathrm{p}<0.05)$ 
Leaf area, leaf dry mass and Dickson quality index were influenced only by substrate correction, with higher values when liming was performed (Table 4). Root area and stem dry mass were influenced by factors apart, with higher values with substrate liming (Table 4), and for the chicken manure dosages the data did not fit the mathematical models tested, with averages of $26.56 \mathrm{~cm}^{2}$ plant $^{-1}$ and $0.87 \mathrm{~g}_{\text {plant }}{ }^{-1}$, respectively. It was observed interaction between chicken manure and substrate correction for root dry mass, without data adjustments to the mathematical models, with an average of 0.83 and $1.67 \mathrm{~g} \mathrm{plant}^{-1}$, without and with liming, respectively.

Table 4. Leaf (LA) and Root (RA) area, Leaf (LDM) and Stem (SDM) dry mass, Dickson quality index (DQI) of C. xanthocarpa on substrate, without and with liming.

\begin{tabular}{cccccc} 
Liming & LA & RA & LDM & SDM & DQI \\
& \multicolumn{2}{c}{$\left(\mathrm{cm}^{2}\right.$ plant $\left.^{-1}\right)$} & \multicolumn{2}{c}{$\left(\mathrm{g} \mathrm{plant}^{-1}\right)$} & \\
\hline Without & $135.79 \mathrm{~b}$ & $16.39 \mathrm{~b}$ & $0.82 \mathrm{~b}$ & $0.58 \mathrm{~b}$ & $2.03 \mathrm{~b}$ \\
\hline With & $248.31 \mathrm{a}$ & $36.73 \mathrm{a}$ & $1.50 \mathrm{a}$ & $1.17 \mathrm{a}$ & $2.43 \mathrm{a}$ \\
\hline C.V. (\%) & 50.31 & 42.79 & 54.01 & 40.31 & 25.62 \\
\hline
\end{tabular}

Means followed by the same letters in the column do not differ by Student's t-test (p>0.05). C.V. (\%) - coefficient of variation.

\section{DISCUSSION}

The chicken manure have limited in the influence of chemical attributes of the substrate, due to fact that it needs more time for process of mineralization of $\mathrm{OM}$, thus releasing nutrients (Silva et al., 2014). This can be seen by $\mathrm{pH}$ of the substrate, without liming, which was 4.79 , even with addition of chicken litter with a $\mathrm{pH}$ of 7.50 , with a small change to the initial pH (4.57). According to Lourenzi et al. (2016), the mineralization of compound organic matter releases $\mathrm{H}^{+}$ ions, raising $\mathrm{pH}$ of the substrate, a fact that did not occur in substrates without liming. However, when adding chicken manure, nutrients were increased readily available in its composition, contributing to increase of attributes compared to analysis of the substrate at the beginning of the experiment.

Silva et al. (2014) studied decomposition and release of N, $\mathrm{P}$ and $\mathrm{K}$ from cattle manure and chicken manure, with a $\mathrm{C} / \mathrm{N}$ ratio close to our study (10.1), they observed that decomposition time of the chicken manure half life, with depth of $0-10 \mathrm{~cm}$ was 231 days after incorporation with soil, while in our study the cultivation was only 165 days, evidencing the limitation of influence of chicken manure on nutrient supply.

The increase of availability of base saturation attributes in the substrate, in which there was liming, is due to the addition of $\mathrm{CaCO}_{3}$ and $\mathrm{MgCO}_{3}$ which promoted reaction with soil $\mathrm{H}^{+}$ions, liberating $\mathrm{Ca}$ and $\mathrm{Mg}$, water and hydrogen oxide, consequently, reducing the substrate acidity. With the $\mathrm{pH}$ increased, toxic $\mathrm{Al}$ was neutralized and potential acidity $(\mathrm{H}+\mathrm{Al})$ decreased. However, micronutrient availability was reversed, as they are less available at high $\mathrm{pH}$ values (Rheinheimer et al., 2018; Auler et al., 2019).

Due to the high availability of macronutrients in the liming substrate, mainly $\mathrm{Ca}$ and $\mathrm{Mg}$, it allowed a better absorption of nutrients such as $\mathrm{N}$ and $\mathrm{P}$, besides $\mathrm{Ca}$ in plants cultivated in this substrate. While the plants grown without liming had higher levels of micronutrients ( $\mathrm{Cu}$ and $\mathrm{Mn}$ ) in their leaves, due to the availability in the substrate. The addition of liming increases root area of C. xanthocarpa in 124\%, compared to plants without liming (Table 4), providing greater absorption of the amount of $\mathrm{K}$, readily available in composition of chicken manure incorporated into the substrate, mainly at the highest dose (Fig. 2).

The highest values of the total chlorophyll index and $b$ with chicken manure and liming, at 150 DAT, respectively, owing to increase in $\mathrm{N}$ present in organic residue $\left(23.90 \mathrm{~g} \mathrm{~kg}^{-1}\right)$ and the leaf content of the plants under liming (Table 2), because $\mathrm{N}$ participates in the structure of chlorophyll molecule (Abrahão et al., 2013), favoring the capture of light.

Similarly, the increase in photochemical indicators, especially the photochemical efficiency of photosystem II $\left(\mathrm{F}_{\mathrm{v}} / \mathrm{F}_{\mathrm{m}}\right)$ at $150 \mathrm{DAT}$, in substrate with liming, is due to the higher content of $\mathrm{P}$ (Table 2) and chlorophylls (Fig. 3) in these same conditions, which contributed to conversion of light energy into chemistry $\left(\mathrm{F}_{\mathrm{v}} / \mathrm{F}_{0}\right)$, attenuating the energy dissipation to be used in electron transfer processes in PS II. The P acts on phospholipid biosynthesis, production of ATP and NADPH (Hernández-Domíguez et al., 2012), leveraging photosynthetic capacity $(A)$. However, it is worth highlighting that the values of these indicators, even in plants grown without liming, were close, demonstrating that soil correction did not directly affect the reaction centers in PS II.

The highest value of $A$ at 79 DAT is associated with lower $C_{i}$, indicating a high efficiency of Rubisco carboxylation and $\mathrm{CO}_{2}$ fixation. On the other hand, at $150 \mathrm{DAT}$, we found responses contrary to those described, since the seedlings reduced their $A$ values even with higher $g_{s}$, suggesting that due to the increase in $E$, less efficient use of water occurred and maintenance of metabolic processes, increasing $C_{\mathrm{i}}$ in the same period. When liming the substrate, we noticed an increase in nutrient content in the leaves, especially $\mathrm{N}$ (Table 2), which participates in synthesis of photosynthetic pigments, regulation of stomatal system and photosynthetic diffusive processes (Mastalerczuk et al., 2017).

Although the values of electron transfer and photochemical yield processes were close to both without and with liming, plants grown on substrate without liming showed reduced 
$\mathrm{CO}_{2}$ fixation $(A)$ and in the functionality of photosynthetic apparatus, due to non-stomatal limitations, reinforcing our hypothesis that substrate correction contributes positively to leaf metabolism and production of photoassimilates in C. xanthocarpa plants. The higher conversion of $\mathrm{CO}_{2}$ fixed in photoassimilates in plants cultivated with liming reflected in higher growth characteristics, such as in height and expansion of leaf area, especially due to higher $\mathrm{N}$ content, since it favors an increase in vegetative characters (He et al., 2015), respectively.

The DQI showed the same values as the other characteristics in the corrected substrate. This indicator has been used to evaluate the quality of seedlings in some fruit trees (Pereira et al., 2018; Gomes Júnior et al., 2019). The increase in DQI is a reflection of the biggest growth indicators (Fig. 5 and 6) and biomass production (Table 4), considering the stability of metabolic processes (Table 3) and morphological characters (Table 4) due to the greater availability of nutrients in the substrate and plant.

The substrate correction with liming and addition of chicken manure, especially the incorporation of $5 \mathrm{Mg} \mathrm{ha}^{-1}$, promoted better indicators growth and physiological benefits in the C. xanthocarpa plant, with higher chlorophyll content in the leaves, as well as lower photochemical stress (Zanandrea et al., 2006; Baker, 2008) reflecting in greater gas exchange (Almeida et al., 2018), thus determining the physiological plasticity of the plant grown under this substrate, as they provided adequate conditions for the species.

\section{CONCLUSIONS}

The liming process allows greater availability of macronutrients and absorption by C. xanthocarpa, but the micronutrients follow in reverse. C. xanthocarpa plants have their development optimized with liming on the substrate and the increase in indicators of growth, photochemical in photosystem II and gas exchange in the incorporation of chicken manure, especially at $5 \mathrm{Mg} \mathrm{ha}^{-1}$. In addition, we found that incorporation of chicken manure requires a longer period in the substrate or use of techniques that accelerate the process of mineralization of organic matter.

\section{SUBMISSION STATUS}

Received: 21 Jan. 2020

Accepted: 15 Oct. 2020

Associate editor: João Vicente de Figueiredo Latorraca

\section{CORRESPONDENCE TO}

\section{Ademir Goelzer}

Universidade Federal da Grande Dourados, Rodovia Dourados/

Itahum, km 12, CEP 79804-970, Dourados, MS, Brasil.

e-mail: ademirgoelzer@gmail.com

\section{REFERENCES}

Abrahão SA, Pinto FAC, Queiroz DM, Santos NT, Carneiro JES. Determination of nitrogen and chlorophyll levels in bean-plant leaves by using spectral vegetation bands and indices. Revista Ciência Agronômica 2013; 44: 464-473. https://doi.org/10.1590/ S1806-66902013000300007.

Almeida EIB, De Medeiros Corrêa MC, Mesquita RO, Queiroz RF, Cajazeira JP, Amorim FFVR. Growth and gas exchanges of red pitaya under different shading conditions. Brazilian Journal of Agricultural Sciences 2018; 13: 1-8. https://doi.org/10.5039/agraria.v13i3a5554.

Alvares CA, Stape JL, Sentelhas PC, De Moraes G, Leonardo J, Sparovek G (2013). Köppen's climate classification map for Brazil. Meteorologische Zeitschrift 2013; 22: 711-728. https://doi.org/ 10.1127/0941-2948/2013/0507.

Auler AC, Caires EF, Pires LF, Galetto SL, Romaniw J, Charnobay AC. Lime effects in a no-tillage system on Inceptisols in Southern Brazil. Geoderma Regional 2019; 16: 1-11. https://doi.org/10.1016/ j.geodrs.2019.e00206.

Baker NR. Chlorophyll Fluorescence: a probe of photosynthesis in vivo. Annual Review of Plant Biology 2008; 59: 89-113. https://doi.org/10.1146/annurev.arplant.59.032607.092759.

Barbieri SF, Amaral SC, Ruthes AC, Petkowicz CLO, Kerkhoven NC, Da Silva ERA, Silveira JLM. Pectins from the pulp of gabiroba (Campomanesia xanthocarpa Berg): Structural characterization and rheological behavior. Carbohydrate polymers 2019; 214: 250-258. https://doi.org/10.1016/j.carbpol.2019.03.045.

Capeletto C, Conterato G, Scapinello J, Rodrigues FS, Copini MS, Kuhn F, Tres MV, Magro JD, Oliveira JV. Chemical composition, antioxidant and antimicrobial activity of guavirova (Campomanesia xanthocarpa Berg) seed extracts obtained by supercritical $\mathrm{CO}_{2}$ and compressed n-butane. The Journal of Supercritical Fluids 2016; 110 : 32-38. https://doi.org/10.1016/j.supflu.2015.12.009.

Carnevali TO, Vieira MC, Luciano AT, Gonçalves WV, Rodrigues WB, Ramos MBM. Crescimento inicial de Campomanesia xanthocarpa O. Berg sob diferentes composições de substratos. Revista Brasileira de Plantas Medicinais 2015; 17: 316-323. https://doi.org/10.1590/ 1983-084X/12_080.

Dickson A, Leaf AL, Hosner JF. Quality appraisal of white spruce and white pine seedling stock in nurseries. Forest Chronicle 1960; 36: 10-13. https://doi.org/10.5558/tfc36010-1.

Gomes Júnior AG, Pereira RA, Sodré GA, Gross E. Growth and quality of mangosteen seedlings (Garcinia mangostana L.) in response to the application of humic acids. Revista Brasileira de Fruticultura 2019; 41: 1-10. https://dx.doi.org /10.1590/0100-29452019104.

He M, Zhang K, Tan H, Hu R, Su J, Wang J, Huang L, Zhang Y, $\mathrm{Li}$ X. Nutrient levels within leaves, stems, and roots of the xeric species Reaumuria soongorica in relation to geographical, climatic, and soil conditions. Ecology and Evolution 2015; 5: 1494-1503. http://dx.doi.org/10.1002/ece3.1441.

Hernández-Domíguez EE, Valencia-Turcotte LG, Rodríguez-Sotres R. Changes in expression of soluble inorganic pyrophosphatases of Phaseolus vulgaris under phosphate starvation. Plant Science 2012; 187: 39-48. https://doi.org/10.1016/j.plantsci.2012.01.009. 
Klafke JZ, Pereira RLD, Hirsch GE, Parisi MM, Porto FG, De Almeida AS, Rubin FH, Schmidt A, Beutler H, Nascimento S. Trevisan G, Brusco I, De Oliveira SM, Duarte MMMF, Duarte T, Viecili PRN. Study of oxidative and inflammatory parameters in LDLr-KO mice treated with a hypercholesterolemic diet: Comparison between the use of Campomanesia xanthocarpa and acetylsalicylic acid. Phytomedicine 2016; 23: 1227-1234. https://doi.org/10.1016/j.phymed.2015.11.010.

Lorenzi H. Árvores Brasileiras - manual de identificação e cultivo de plantas arbóreas nativas do Brasil. 5th ed. Nova Odessa: Instituto Plantarum; 2008.

Lourenzi CR, Scherer EE, Ceretta CA, Tiecher TL, Cancian A, Ferreira PAA, Brunetto G. Atributos químicos de Latossolo após sucessivas aplicações de composto orgânico de dejeto líquido de suínos. Pesquisa Agropecuária Brasileira 2016; 51: 233-242. https://doi.org/10.1590/S0100-204X2016000300005.

Malavolta E. Manual de nutrição mineral de plantas. São Paulo: Editora Agronômica Ceres; 2006.

Mastalerczuk G, Borawska-Jarmułowicz B, Kalaji HM, Dąbrowski P, Paderewski J. Gas exchange parameters and morphological features of festulolium (Festulolium braunii K. Richert A. Camus) in response to nitrogen dosage. Photosynthetica 2017; 55: 20-30. http://dx.doi.org/10.1007/s11099-016-0665-0.

Melo RM, Vieira MC, Carnevali TO, Goncalves WV, Tolares EP, Menegati SELT, Santos CC. Calagem e textura do substrato afetam o desenvolvimento de Campomanesia adamantium (Cambess.) O. Berg. Revista de Ciências Agrárias (Lisboa) 2019; 42: 99-108. https://dx.doi.org/10.19084/RCA18283.

Otero JS, Hirsch GE, Klafke JZ, Porto FG, De Almeida AS, Nascimento S, Schmidt A, Da Silva B, Pereira RLD, Jaskulski M, Parisi MM, Guarda NS, Moresco RN, Aita CAM, Viecili PRN. Inhibitory effect of Campomanesia xanthocarpa in platelet aggregation: Comparison and synergism with acetylsalicylic acid. Thrombosis research 2017; 154: 42-49. https://doi.org/10.1016/j.thromres.2017.03.020.

Pereira RA, Gomes Júnior AG, Almeida G, Rodrigues EM, Sodré GA, Sacramento CK. Matrix management interfers in yield and quality of cocoa seedlings. Revista Brasileira de Fruticultura 2018; 40: 1-8. https://dx.doi.org/10.1590/0100-29452018582.
Rheinheimer DS, Tiecher T, Gonzatto R, Zafar M, Brunetto G. Residual effect of surface-applied lime on soil acidity properties in a long-term experiment under no-till in a Southern Brazilian sandy Ultisol. Geoderma 2018; 313: 7-16. https://dx.doi.org/10.1016/ j.geoderma.2017.10.024.

Salmazzo GR, Verdan MH, Silva F, Cicarelli RM, Mota JDS, Salvador MJ, Carvalho JE, Cardoso CAL. Chemical composition and antiproliferative, antioxidant and trypanocidal activities of the fruits from Campomanesia xanthocarpa (Mart.) O. Berg (Myrtaceae). Natural product research 2019; 1: 1-5. https://doi.org/10.1080/14786419.2019.1607333

Santos HG, Jacomine PKT, Anjos LD, Oliveira VD, Oliveira JD, Coelho MR. Sistema brasileiro de classificação de solos. 3rd ed. Rio de Janeiro: Embrapa Solos; 2013.

Silva FC. Manual de análises químicas do solo, plantas e fertilizantes. 2nd ed. rev. Ampliada. Brasília: Embrapa Informação Tecnológica; Rio de Janeiro: Embrapa Solos; 2009.

Silva BV, Silva AP, Dias BO, Araujo JL, Santos D, Franco RP. Decomposição e liberação de N, $\mathrm{P}$ e K de esterco bovino e de cama de frango isolados ou misturados. Revista Brasileira de Ciência do Solo 2014; 38: 1537-1546. https://dx.doi.org/10.1590/S0100-06832014000500019.

Soratto RP, Crusciol CAC. Atributos químicos do solo decorrentes da aplicação em superfície de calcário e gesso em sistema plantio direto recém implantado. Revista Brasileira de Ciência do Solo 2008; 32: 675-688. https://dx.doi.org/10.1590/s0100-06832008000200022\&route=6

Sousa DMG, Lobato E. Cerrado: soil correction and fertilization. 2nd. ed. Embrapa Informação Tecnológica: Rio de Janeiro; 2004.

Torres DM, Fontes MAL, Samsonas HP. Soil-vegetation relationships in structuring cerrado sensu stricto communities in southern Minas Gerais, Brazil. Rodriguésia 2017; 68: 115-128. https://dx.doi.org/10.1590/2175-7860201768121.

Vallilo MI, Moreno PRH, De Oliveira E, Lamardo LCA, Garbelotti ML. Composição química dos frutos de Campomanesia xanthocarpa Berg-Myrtaceae. Ciência e Tecnologia de Alimentos 2008; 28: 231-237.

Zanandrea I, Nassi FL, Turchetto AC, Braga EJB, Peters JA, Bacari MA. Efeito da salinidade sob parâmetros de fluorescência em Phaseolus vulgaris. Revista Brasileira Agrociência 2006; 12: 157-161. https://dx.doi.org/10.18539/cast.v12i2.4512. 